\title{
コガタアカイエカの時刻的消長について*
}

\section{Observations on the diurnal change of Culex tritaeniorhynchus}

園田浩1)

Hiroshi Sonoda

ライトトラップによるコガタアカイエカの時刻的消長 は多くの研究者によって調心゙られている（池内4)，含

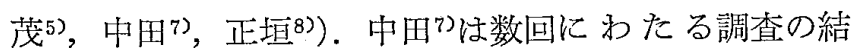
果,ライトトラップによって示された時刻的消長と温度, 湿度などの気象的要因の間に相関が認められないことを

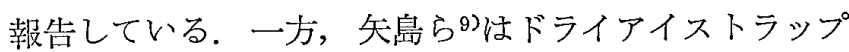
等によってコガタアカイエカの夜閒活動個体群の年龄構 成を調心゙，年齡構成功日周期的変化をしていることを報 告している.

これらの報告より，蚊個体群の時刻的消長は個体群の 年齢構成の変動と関連があるのではないかと考㝋，1967 年に時刻的消長を，1968年に生理的年龄定調べ，若干の 知見を得そので報告する.

本文にはいるにさきだち，終始御指導いただいた大阪 府立大学, 伊藤修四郎教授, 校閲を賜つた大阪府立公衆 衛生研究所, 武衛和雄博士に感謝の意を表する。

\section{調查場所および方法}

調查地点として図 1 亿示したように周囲が水田にかこ まれた住宅地の中にある牛舎の密の外に設置した。 トラ ップは 6 Wのブラックライトを光源とする野沢式ライト トラップを用いた。設置した場所よりトラップの光は水 田まではとどかない。

時刻的消長は1967年 8 月から 9 月にか沙ておよそ 1 週 間間隔で 8 回調查した。年回，日没時から日の出まで卜 ラップの下部にある捕虫かごを 1 時間ごとに交換し，各 時間内に採れた蚊の種類, 性別, 個体数を記録した. ま た，1968年 7 月から 8 月にがて 19 20 時および 3〜 4 時の間にライトトラップで採集された未吸血個体を解 剖して卵巣を摘出し，Detinova ${ }^{33}$ の方法によつて濾胞の 発育段階をしらべ，濾胞管に形成される dilatation を

* 本報告の要旨ほ第21回日本衛生動物学会大会 (1969長崎）で報告した。

1) 大阪府立大学農学部昆虫学教室

Entomological Laboratory, College of Agriculture, University of Osaka Prefecture, Sakai, Osaka

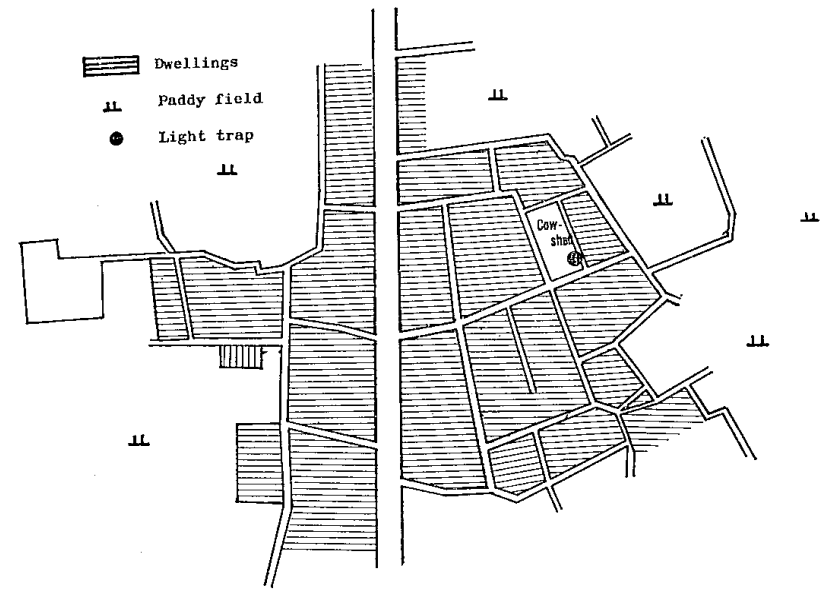

Fig. 1. Sketch map showing the study site, Haze, Sakai City, Osaka Prefecture

みることによつて経産か未経産かを区別し，またその数 によって経産回数を判定した。

\section{結果}

1967年，1968年の両年を通じて採集された蚊はコガタ アカイエカ*, Culex tritaeniorhynchus, アカイエカ Culex pipiens pallens, ニガタクロウスカ Culex hayashii, トラフカクイカ Culex vorax, シナハマダラカ Anopheles hyrcanus sinensis, ヒトスジシマカ Aedes albopictus, キンイロヤブカ Aedes vexans, オオクロヤ ブカ Armigeles subalbatus の 4 属 8 種であつた. コガ タアカイエカはこれらの種のうちで最も多く採集され， 1967 年には全採集個体数の $92 \% ， ' 68$ 年には $48 \%$ を占め た。両年のコガタアカイエカの季節的消長を比較してみ ると，1968年の最盛期の採集個体数が1967年のそれに比 べて著しく少なかった（図 2 )。採集個体のうちで末吸血 雌，吸血雌，雄の割合は，1967年にはそれぞれ，99.4， $0.2 ， 0.4 \% ， ' 68$ 年は，94.5，1.8，3.6\%で両年ともに 未吸血雌が採集個体のほとんぞを占めていた。

未吸血コガタアカイエカの時刻的消長を図 3 亿示す. 全体として前半夜と後半夜に peak のあらわれる 2 山型

*正確には，シロハシイエカCulex vishnui が若干 含まれているものと思われる。 


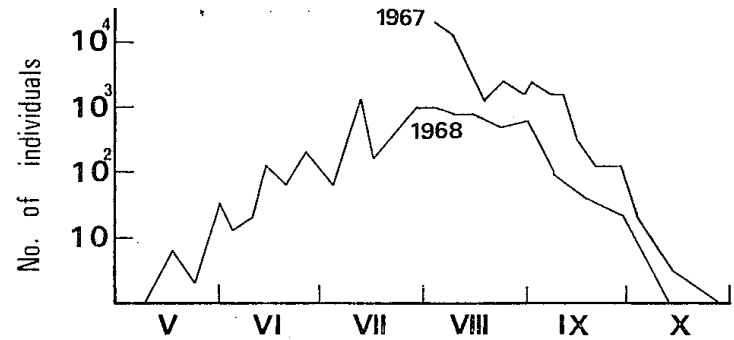

Fig. 2. Seasonal prevalence of Culex tritaeniorhynchus

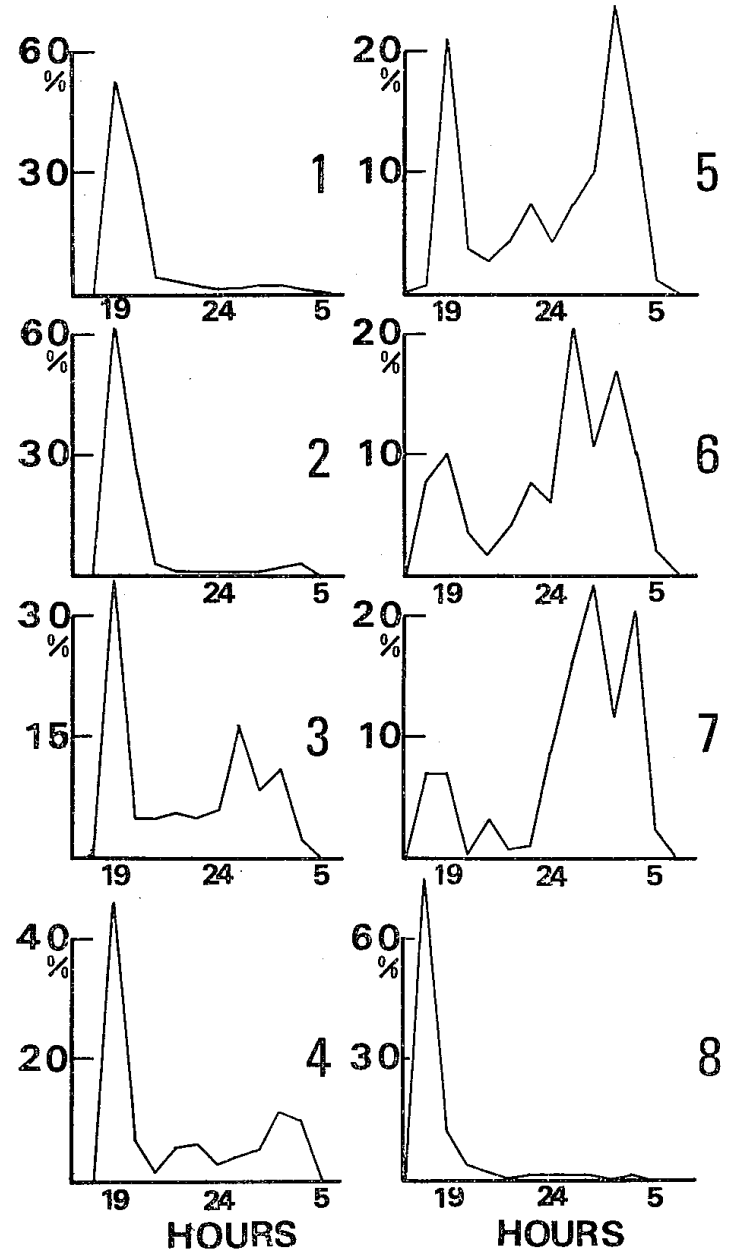

Fig. 3. Hourly changes of Culex tritaeniorhynchus as indicated by light traps

1 : Aug. 3-4, '67, 2 : Aug. 9-10, '67, 3 : Aug. 18-19, '67, 4 : Aug. 24-25, '67, 5 : Sept. 1-2, '67, 6 : Sept. 7-8, '67, 7 : Sept. 15-16, '67, 8 : Sept. 21-22, '67.

のパターンで示された，第 1 回，2 回の調査では19 20 時に高い peak が見られ，3〜4 時の peak 活非常に低 かつた．第 3 回，4回の調查で19〜20時に前半夜の peak が観察されるが，第 3 回は $1 \sim 3$ 時に，第 4 回は $3 \sim 4$ 時に後半夜の peak が認められた。 前半夜の peak 注第 5 回の調查において等しい高さとなり，第6回，7回に 注後半夜の peak の方が前半夜のそれよりも高くなつ た. そして第 8 回の調查では再び日没後 1 時閒の間に高
い peak があらわれた。

1 回〜 7 回の調查時における気温は $30 \sim 20^{\circ} \mathrm{C}$ であつ た. ところが 8 回目の調查では日没後 1 時間は $20^{\circ} \mathrm{C}$ で あつたのが，その後急速にさがり最低 $14^{\circ} \mathrm{C}$ を記録し た.したがつて，第 8 回目の時刻的消長は気温の影響を 強く受けているものと思われる.

雌個体の剖検結果流 1 の通りである。調查期閒を通 こで経産蚊の滤胞の発育期の頻度分布は，19 20時お よび 3〜 4 時の両方ともほぼ同じ組成を示した。すなる ら 7 月中够では I II期および II期の個体が多く，8月 に入つて I 期の個体が増し，下旬には再び I ～II期およ びா期が多くなつた。 ところが両時間帯の経産蚊率（経 産蚊数/剖検蚊数 $\times 100 ）$ は異なつており，前半夜の蚊の 経産蚊率は後半夜のそれと比較して明らかに低い傾向が 認められた。 また，濾胞管が sac 状の stage を示す個 体が主に後半夜の経産蚊の中に含まれていた。

\section{考察}

蚊の活動消長を調べるためライトトラップがよく使用 されている. Corbet²)はライトトラップに採集された蚊 は， swarming, ovipositing, biting のような特別な活 動をしているのではなく， non-specific activity と認め られる個体であると報告している，確かに囮法における 採集のように採集された個体の行動を直接判定はできな いであろらが，トラップの設置場所むるいは採集個体の 性比などによつてトラップに採集された個体がどのよう な活動をしていたかを知ることができると思われる。こ の調査では, トラップを牛舎の空の外に設置しているこ と，水田にトラップの光が達しない状態であったことか ら，採集された雌は吸血のため牛舎に飛来した個体群と 考えてもよいだろう，このことはさきに述べた性比ある 、注吸血個体さ未吸血個体の割合からも推定できる。

コガタアカイエカの時刻的消長を調べると双峰型を示

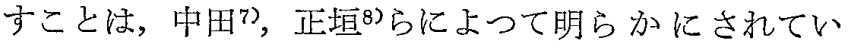
る.ところが時刻的消長を一定期閒連続して調心゙，両 peak の形成される原因や年齢組成を peak の高さが個 体群の増減にともなつて变動することから解析した報告 はない。

気温の変動によつて説明のできる第 8 回の時刻的消長 学除いて，前半夜の peakおよび後斗夜の peak の採集 個体数（各 peak の採集個体数注 2 時間を単位として いる）と終夜採集個体数の関係を図 4 に示す. 前半夜の peak 時の採集個体数注，終夜採集個体数が増すにした がつて増加するが，後半夜の peak 時の採集個体数はあ まり変動していない。このことは終夜採集個体数が多い 時にはほとんどの個体が前半夜の peakに出現している 
Table 1. Incidence of nulliparous and parous females of Culex tritaeniorhynchus caught by light traps at 19-20 and 03-04 hours

\begin{tabular}{|c|c|c|c|c|c|c|c|c|c|}
\hline & & JUI & & & & AUC & $\mathrm{ST}$ & & \\
\hline \multirow{12}{*}{ 19-20 hours } & Date & 12 & 18 & 29 & 3 & 10 & 15 & 23 & 31 \\
\hline & No. of dissect. & 50 & 14 & 33 & 39 & 50 & 50 & 38 & 31 \\
\hline & Nulliparous & & & & & & & & \\
\hline & Ovary stage $N$ & 0 & 0 & 5 & 6 & 7 & 1 & 0 & 0 \\
\hline & $I$ & 5 & 0 & 10 & 15 & 23 & 25 & 12 & 2 \\
\hline & $\mathrm{I}-\mathrm{II}$ & 14 & 8 & 2 & 6 & 3 & 6 & 7 & 11 \\
\hline & II & 30 & 5 & 14 & 6 & 4 & 7 & 7 & 11 \\
\hline & Parous & & & & & & & & \\
\hline & Monoparous $\underset{\mathrm{S}}{\mathrm{D}} *$ ** & 1 & 1 & 2 & 5 & 12 & 10 & 9 & 7 \\
\hline & D. & 0 & 0 & 0 & 1 & 0 & 1 & $\begin{array}{l}2 \\
0\end{array}$ & 0 \\
\hline & Biparous $\quad \mathrm{S}$. & 0 & 0 & 0 & 0 & 0 & 0 & 1 & 0 \\
\hline & Parous rate & 2.0 & 7.1 & 6.1 & 15.3 & 26.0 & 22.0 & 31.5 & 22.5 \\
\hline \multirow{11}{*}{ 03-04 hours } & No. of dissect. & 50 & 5 & 37 & 42 & 50 & 49 & 30 & 31 \\
\hline & Nulliparous & & & & & & & & \\
\hline & Ovary stage $N$ & 3 & 0 & 3 & 5 & 3 & 0 & 0 & 0 \\
\hline & & 0 & 0 & 10 & 13 & 25 & 28 & 8 & 3 \\
\hline & $I-I I$ & 7 & 2 & 6 & 11 & 3 & 4 & 5 & 8 \\
\hline & II & 26 & 2 & 11 & 6 & 2 & 11 & 7 & 9 \\
\hline & Parous & & & & & & & & \\
\hline & Monoparous D. & 2 & 1 & 2 & 3 & 11 & 4 & 4 & 10 \\
\hline & Lvevituparous S. & 12 & 0 & 4 & 4 & 6 & 1 & 6 & 1 \\
\hline & Biparous $\quad$ S. & $\begin{array}{l}0 \\
0\end{array}$ & $\begin{array}{l}0 \\
0\end{array}$ & $\begin{array}{l}0 \\
1\end{array}$ & $\begin{array}{l}0 \\
0\end{array}$ & $\begin{array}{l}0 \\
0\end{array}$ & $\begin{array}{l}1 \\
0\end{array}$ & $\begin{array}{l}0 \\
0\end{array}$ & $\begin{array}{l}0 \\
0\end{array}$ \\
\hline & Parous rate & 28.0 & 20.0 & 18.9 & 16.6 & 34.0 & 12.2 & 33.3 & 35.4 \\
\hline
\end{tabular}

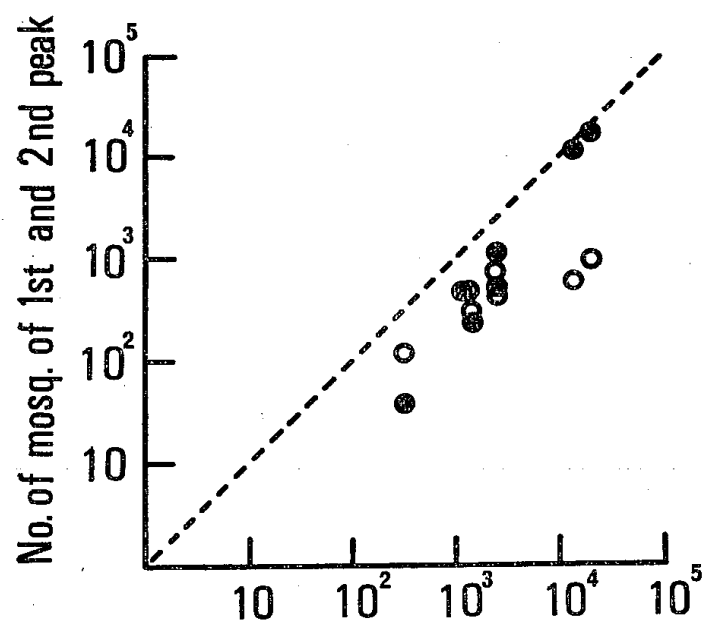

No. of mosq. of all night collection

Fig. 4. The relationships between numbers of each peak and numbers of all night collection

(-) numbers of 1 st peak

(O) numbers of 2nd peak
ことを示している．終夜採集個体数が多い時期はコガタ アカイエカの最盛期を示し，最盛期の個体群では新生蚁 が最も多いと考えられるから，図 4 は新生蚊が前半夜の peak に出現することを示しているようである。同じよ うに，終夜採集個体数が減少するに従つて前半夜の peak 時の採集個体数も急激に減じることからも新生蚁 が前半夜の peakに出現していることが推測できる。一 方, 後半夜の peak 時の採集個体数梳, 終夜採集個体数 の増減に伴ら前半夜の peak 時の個体数の変動活ど変化 しないこと定示しているが，このことは後半夜の peak が前半夜の peak と異つた年齢の個体群によって構成さ れていることを示唆する。剖検結果より前半夜の個体群 の経産蚊率の方が後半夜のそれより低いことがわかつ た。経産，未経産は直接 calendar age を示さないが， 前半夜の peak は主に新生蚊あるいは young female, 後半夜の peak は主に old female によつてそれぞれ構 成されていることが推定できる。

中田は73 1956 年 8 月上旬 8 月下旬の実験で第 1 回の 
調查には雌雄ともに，日没後 1 時間附近に顕著な山を示 し，以後深夜に向かつて急激に減少し，日の出の 1 時間 程前にきわめて小さい第 2 の山のあらわれる消長を示 し, 以後実験の回が進むにつれて, 第 1 の山が次第にく ずれてゆき，反対に第 2 の山が次第に高くなつて，第 4 回の調查で法後の山の方が高くなつてくると報告してい る。これはトラップを水田内に設置しているため，吸 血活動をするコガタアカイエカ個体群とは異つた behaviour を示すかもしれないが，今回の調查の peakの 変動が中田の成績と似ていることは興味深い.

Lumsden ${ }^{6}$ は $2 つ の$ peak 浊異つた年龄の蚊によって 形成されるという仮説を報告している. 生理的年齢構成 の日周期的変化をしらべた矢岛ら ${ }^{90}$ の報告によると，豚 舎で採集されたコガタアカイエカの経産蚊率注前半夜よ り後半夜に高い傾向があり，その差は日没後 $1 \sim 2$ 時間 と日の出前 $1 \sim 2$ 時閒に顕著であつたという.

この実験で，コガタアカイエカ個体群の夜間活動にお いて，年龄によつて活動時刻が変動することが明らかと なつた。 この年齢構成の変動は日没後に新生蚊が活動す ることによるものと思われ，また時刻的活動消長は個体 群の年齢構成が反映していると推定される。

\section{摘 要}

周囲が水田にかこをれた住宅地の中にある牛舎の外に ライトトラップを設置し，1967年 8～9 月にコガタアカ イエカの時刻的消長を, '68年 $7 \sim 8$ 月に雌個体の生理的 年齢を調べた。

(1) コガタアカイエカの時刻的消長は前半夜と後半夜 に山のあらわれる 2 山型を示すが，その peak の高さは 季節にともなつて変動した.

（2）前半夜の雌個体群の経産蚊率は，後半夜のそれよ りを低く, 前半夜の peak 注主として新生蚊の出現によ つて構成されるものと思われる。

(3) これらのことから，コガタアカイエカの時刻的活 動消長は個体群の年龄構成が反映していると推測され た.

\section{文献}

1) Clements, A. N. (1963) : The physiology of mosquitoes. 393pp. Pergamon Press Oxford. -2) Corbet, P. S. (1961) : Entomological studies from a high tower in Mpanga forest, Uganda. VI Nocturnal flight activity of Culicidae and Tabanidae as indicated by light traps. Trans. Ray. Ent. Soc. Lond., 113 : 301-314. -3) Detinova, T. S. (1962) : Age-grouping methods in Diptera of medical importance. 216pp. WHO, Geneva. -4) 池内束き子 (1968)：Light trap によるコガタアカ イエカの採集(抄)。衛生動物，19(2)：111．－5) 倉茂好雄 (1969)：宇都宮市のライトトラップに採集 された蚊の時刻的消長. 衛生動物，20(4):236-239. -6) Lumsden W. H. R. (1952) : The crepuscular biting activity of insects in the forest canopy in Bwamba, Uganda. A study in relation to the sylvan epidemiology of yellow fever. Bull. Ent. Res., 42:721-760. 一7) 中田五一(1962) : 日本産蚊雷科の分類学的並びに生熊学的研究. 衛生 害虫，6(5-12)：41-173。一-8) 正垣幸男 (1968)：名 古屋市の中心地に扔いて夏季にライトトラップによ り採集したコガタアカイエカ群の時刻的変化(抄). 衛生動物，19(2): 112. 一9) 矢島孝昭, 加藤陸奥雄, 吉田勝一，渡辺孝男，石井孝(1967)：コガタアカイ 工力個体群の生理的年龄構成からみた日周期活動. 日本生態学会第 14 回大会講演集， $36 。-10)$ 矢島孝 昭, 吉田勝一, 石井孝, 加藤陸奥雄 (1968)：コガタ アカイエカの日周活動一生理的年齢㐨よび暦年跉か らの解析，日本生態学会第 15 回大会講演集，109110 .

\section{Summary}

Observation of nocturnal flight activity of Culex tritaeniorhynchus was carried out by means of hourly collection in a light trap and the dissection of the females. The diurnal changes of C. tritaeniorhynchus showed a bimodal pattern and the height of two peaks fluctuated regularly according to population trend. When numbers caught through the night increased, numbers in the first peak increased remarkable but those in the second peak slightly. The proportion of numbers in the first peak for numbers caught through the night increased to almost $90 \%$. The parous rate at $19-20 \mathrm{hrs}$. was lower than that at 03-04 hrs, and in parous females caught at 03$04 \mathrm{hrs}$. there were many individuals that the condition of the connecting stalk of follicle showed sac like. These observations suggest that the age-composition fluctuates through the night in nocturnal flight activity of female population. 